\title{
"Nature" and the "Nature of Things" in the Stoic Philosophy of Epictetus: A Synopsis
}

\author{
By Franco Scalenghe*
}

\begin{abstract}
Up to now the interpretation of the Stoic philosophy of Epictetus has completely ignored the concept of "Nature of things." The purpose of this paper is to demonstrate the fundamental importance and the constant presence of this concept in the works of Epictetus, provided that we look carefully at

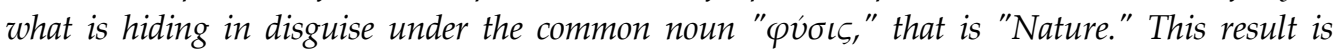
obtained and documented through the simple logical analysis of all the relevant passages in the works of Epictetus.
\end{abstract}

\section{Introduction}

While analyzing a recent Italian and English translation from ancient Greek of all the works of Epictetus, ${ }^{1}$ I became gradually more and more aware that, for a correct interpretation of his Stoic philosophy it is essential to recognize that the noun $\varphi v$ ors ("physis"), in addition to its usual meaning of "Nature," has also the very specific and technical meaning of "Nature of things."

A couple of remarks are worth making with regard to this. The first is that this meaning is not of random and occasional occurrence in Epictetus. As the frequencies calculated below demonstrate, out of a total of 179 occurrences of the noun $\varphi v \sigma_{\iota} \iota$, in 76 cases, that is in more than $42 \%$ of the cases, it is possible to give a consistent and precise meaning to the words of Epictetus only by making $\varphi v \boldsymbol{\sigma} \iota s$ mean the "nature of things." The second is that since all the previous translations, be they partial or complete, of the works of Epictetus by Cesare Cassanmagnago, ${ }^{2}$ Robert Dobbin, ${ }^{3}$ or Pierre Hadot ${ }^{4}$ to name a few, ignore the concept of the "nature of things," the present research moves on a ground unexplored and lacking any bibliographic support.

* Independent Scholar, Former member of the Laboratorio Internazionale di Genetica e Biofisica (LIGB) of the CNR (National Research Council), Italy.

1. A new Italian and English translations of all the works of Epictetus is available online at www.epitteto.com. 1982).

2. Cesare Cassanmagnago, Epitteto: Diatribe, Manuale, Frammenti (Rusconi Editors,

3. Robert Dobbin, Epictetus. Discourses Book I (Oxford: Oxford University Press, 2008).

4. Pierre Hadot, Manuale di Epitteto (Einaudi Editors, 2006). 
All the present quotations of the works of Epictetus as edited by William Abbott Oldfather ${ }^{5}$ are taken from my new English translation. ${ }^{6}$ Moreover, in this paper all my quotations of the "Memoirs" of Marcus Aurelius as edited by Joachim Dalfen ${ }^{7}$ and of the "Stoicorum Veterum Fragmenta" as edited by Hans von Arnim ${ }^{8}$ are taken from my new and unabridged Italian translation of both these texts.

\section{The Double Meaning of the Word "Nature" in Epictetus}

Let us take an example among many, that of (NOT22) "Discourses" I,22,9. To my knowledge, until now all the scholars have translated this passage essentially this way: "What, then, does it mean to get an education? It means learning to apply natural preconceptions to particular cases in accordance with nature. And further, it means making the distinction that some things are in our power while others are not." 9 What does it mean "in accordance with nature"? Which "nature" are we talking about? Whatever thing we do or happens in the world, will it not be a "natural" thing? Is it possible for a man to operate in a way that is "contrary to nature"? All translators evidently think that this last thing is possible, but this assumption is false, absurd, impossible and contradictory. Epictetus knows very well how easy it is to misunderstand the point, and interpret as "nature" things that are simply "cultural models." Therefore he avoids this mistake and immediately comes to the help of his translator, by warning him that he was referring not to "nature" in general, but to the absolute standard represented by the "nature of things." The "nature of things" is precisely their essential bipartition in things that are in our exclusive power and things that are not in our exclusive power. Reasonably, it ensues that the correct translation of this fragment cannot be but the following: ${ }^{10}$ "What does it mean then to educate ourselves? It means learning to adapt our natural preconceptions to the particular substances and cases in a way appropriate to the nature of things and, well then, to discriminate that, among things, some are in our exclusive power while others are not in our exclusive power."

5. William Abbott Oldfather, Epictetus. The Discourses as reported by Arrian, the Manual and the Fragments (London: Heinemann, 1961).

6. www.epitteto.com.

7. Joachim Dalfen, Marci Aurelii Antonini "Ad se ipsum Libri XII" (The Emperor Marcus Aurelius Antoninus "To himself, books 12") (Leipzig: Teubner, 1979). A new Italian translation by Franco Scalenghe, 2009, is available online at www.epitteto.com.

8. Hans von Arnim, "Stoicorum Veterum Fragmenta" (Stoic Ancient Fragments) (Leipzig: Teubner, 1905). A new Italian translation of the SVF by Franco Scalenghe, 2015, is available online at www.epitteto.com.

9. Dobbin, Epictetus. Discourses Book I.

10. www.epitteto.com. 
I believe that this is a matter of fundamental importance, since the concepts of "nature of things,"11 of "proairesis"12 and of "diairesis,"13 are closely interrelated and represent three fundamental pillars of the Stoicism of Epictetus that have been until now dramatically undervalued or even completely ignored. Which is therefore the difference between "nature" and the "nature of things"? Considering that, according to the Stoics, ${ }^{14}$ one and the same nature gives birth, grows, changes and kills men, animals, vegetables and minerals, we can say that for the Stoics "Nature" (together with Proairesis, Fortune and Necessity) is one of the four basic causes ${ }^{15}$ of all events in the cosmos and a divine and all-encompassing entity able to accept any kind of human behavior. Therefore the man, like any other being, lives always in accordance with nature simply because it is impossible for him to escape death, ${ }^{16}$ and, as a consequence, to live in a way "contrary to nature." 17 In its turn, as Epictetus points out, the "nature of things" is the essential bipartition of all the existing reality into "aproairetic" (that is "not in our exclusive power") and "proairetic" (that is "in our exclusive power") things. ${ }^{18}$ Accordingly, this means that "nature" does not need the existence of human beings, while the "nature of things" needs the existence of human proairesis. And it is in relationship to the compliance with, or to the attempted violation of, not "nature" - because this is simply impossible - but of the "nature of things" - which, on the contrary, is quite possible - that men divide themselves into virtuous and vicious, into happy and unhappy, into free and slaves, into living peace and living war. ${ }^{19}$

\section{Methodology of the Synopsis}

A terminological clarification about the Stoicism of Epictetus will not be out of order at this point. Nature is understood by Epictetus in two interrelated and clearly distinguishable ways. The first is "nature" in the

11. Franco Scalenghe, The nature of things. A dialogue (Available online at www.epitteto.com, 2014).

12. Scalenghe, "About the Arithmetic and the Geometry of Human Proairesis and the Natural Asymmetry by Which Unhappiness Wins the Game Against Happiness 3

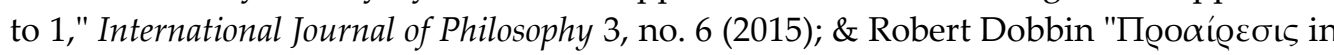
Epictetus," Ancient Philosophy 11 (1991).

13. Scalenghe, "Epictetus: Diairesis and Contradiairesis," Prometeus Ano 7, no. 15, Janeiro-Junho (2014).

14. Laertius Diogenes, Stoicorum Veterum Fragmenta (Book III, Fragment 178).

15. Marci Aurelii Antonini, "Ad se ipsum" (To himself) (Book II, ch. 3, 1-3).

16. Epictetus, "Discourses" (Book I, ch. 27, 9).

17. Laertius, "Stoicorum Veterum Fragmenta" (Book III, Fragment 4).

18. Epictetus, "Manual" (I, 1).

19. Ibid., "Discourses" (Book IV, ch. 1, 1-5). 
common sense of the all-inclusive entity that is usually called Universe and is considered as Matter Immortal obeying a rational order, a being which precedes the existence and survives the disappearance of the human proairesis. The second is "nature" in the sense just said but in which, however, the human proairesis has been naturally generated and is present. In the first case, the Universe is defined by a single set of things because, due to the absence of the human proairesis, it is made only of aproairetic things. In the second case, due to the existence in it of the human proairesis, the Universe is defined by two distinct sets of things: a) the proairetic things and b) the aproairetic things. ${ }^{20}$ The difference between "nature" and the "nature of things" is then due to the presence or the absence in the Universe of the human proairesis: when and where the proairesis exists, there the nature of things exists; and when and where there is no proairesis, there the nature of things does not exist.

It seems then appropriate to divide the synopsis into three sections. The first section contains all the quotations of the works of Epictetus in which the noun $\varphi$ v́⿴\zh11s ("physis") has the common and usual meaning of "nature." I will mark them with the letter $\mathrm{N}$ followed by a number (N1, N2, etc.). In this section therefore, I will keep myself close to the current translations. The second section contains all the quotations for whom I propose the translation of the noun $\varphi v$ oı $\varsigma$ with "nature of things." In this section I will break away from the translations published so far. I will mark them with NOT (=Nature of Things) followed by a number (NOT1, NOT2, etc.). The third section contains all the quotations in which Epictetus employs the noun $\varphi v$ oı $\varsigma$ to indicate first "nature" and then the "nature of things," in this or in the reverse order. In some cases, fortunately few, the difference between the two possible interpretations of the text of Epictetus is very subtle. The elucidation of these subtleties would require a discussion which goes however beyond the precise and limited scope of the present paper.

20. Franco Scalenghe, "Proairesis, Proairetic and Aproairetic: Synopsis of All the Passages Containing these Terms in the "Discourses" and the "Manual" of Epictetus," International Journal of Philosophy 3, no. 3 (2015). 


\section{The Synopsis}

\section{Quotations Containing the Noun $\Phi v$ oı $\varsigma$ with the Meaning "Nature"}

(N1) - Blows are not unbearable by nature.

"Discourses" I,2,2

(N2) - And unless we act appropriately, methodically, consequently to the nature and structure of each, we shall no longer hit the mark of our own ends. "Discourses" I,6,15

(N4) - On the contrary, will it be necessary for our philosopher to set off having confidence in and leaning on others, to take no care of himself, and to be worse and more cowardly than the beasts lacking reason, each of whom is content with itself and is at a loss neither for its own food nor for enjoying itself in a way which is appropriate and in accord with nature?

"Discourses" I,9,9

(N6) - Will you not remember what you are and over whom you rule? That you rule over congenerous, over brothers by nature, over descendants of Zeus?

"Discourses" I,13,4

(N7) - But just as the soldiers are ready for the general shod, clothed and armed; and it would be strange if the commander needed to go around shoeing and clothing thousand people; so nature also has made the creatures born for service ready, prepared, in need of no further diligence.

"Discourses" I,16,4

(N8) - Come on, let's give up the main works of nature and observe its accessory works.

"Discourses" I,16,9

(N9) - Does the nature of each of us not cry aloud straightaway from afar: "I am a male; as such come to me, as such chat with me and don't seek other things: behold the tokens"?

"Discourses" I,16,11

(N10) - I come and inquire further what this interpreter of the nature says. I begin not to comprehend what he says and I look for someone able to explain it to me.

"Discourses" I,17,16

(N11) - For we have no need of Chrysippus on his own account, but in order to understand the nature.

"Discourses" I,17,18

(N12) - He takes them, spreads them out and explains: "Man, you have a proairesis by nature unhampered and unconstrained. Here, in the entrails, this has been written.

"Discourses" I,17,21 
(N13) - In general, Matter Immortal fashioned the nature of the rational creature in such a way that he could not hit the mark of any of his own goods unless he furnished some common benefit.

"Discourses" I,19,13

(N14, 15) - Therefore for what purpose has reason been assumed by nature? For the use as it must be of the impressions. And what is reason itself? A system of impressions of a certain kind: so reason becomes by nature able to know its own general principles too.

"Discourses" I,20,5

$(\mathrm{N} 16,17)$ - Tell me: "What is, then, god and what is impression? And what is the nature of the "particular" and what is the nature of the "whole"?"

"Discourses" I,20,16

(N18) - Epicurus also has the notion that we are by nature sociable beings, but once he has set our good in the shell he can say nothing else.

"Discourses" I,23,1

(N19) - It is impossible, then, to assent to what does not appear to be there. Why? Because this is the nature of the intellect: to nod to the truth, to be ill pleased with the false, to suspend judgement in doubtful cases.

"Discourses" I,28,2

(N20) - Show me that he who has worse judgements masters the one who is better than him in judgements. You will not show it; no, nor you will even come near to show it. For the law of the nature and of Zeus is this: let the best always prevail over the worst. In what? In that in which it's best.

"Discourses" I,29,19

(N21) - And it is shameful that philosophers also be spectators of the works of nature in this way.

"Discourses" I,29,60

(N22) - For if it is sound what has been often said and often demonstrated, namely that the substance of the good as well as that of the evil is in the use of our impressions, while that which is aproairetic admits neither the nature of evil nor that of good ...

"Discourses" II,1,4

(N23, 24) - Therefore, as it is likely to happen to those who heavily aberrate in the greatest issues, that which is in us by nature courageous, this we fashion brazen, insane, haughty, shameless; whereas that which is in us by nature cautious and self respecting, this we fashion cowardly and wicked and full of fears and disconcertments.

"Discourses" II,1,11

(N25) - If you dispose to keep unconditioned the things that are in your exclusive power and are free by nature and to be content with that, what do you turn anymore your mind towards?

"Discourses" II,2,3 
(N26) - If you want instead to keep the external objects too, your body, your petty properties, your petty dignity, I tell you: make immediately all the preparation you can and, well then, analyse the nature both of the judge and of your adversary.

"Discourses" II,2,10

(N27) - If this is shameful, discriminate immediately: "Where is the nature of the evil and the good things? Where truth also is."

"Discourses" II,2,14

(N28) - What then? Are not ladies a common property by nature? I also say this.

"Discourses" II,4,8

(N29) - In this sense the ladies also are common by nature.

"Discourses" II,4,10

(N30, 31, 32) - How, then, is it said that of the external objects some are in accord with nature and others are not in accord with nature? It is as if we were absolute beings. For I'll say that for the foot itself it is in accord with nature to be clean, but if you take it as a foot and not as an absolute thing, it will be a proper deed for the foot to step into the mud, to trample on thorns and in case of need to be amputated for the sake of the whole body.

"Discourses" II,5,24

(N33) - What are you? A human being. If you consider yourself as an absolute thing, it is in accord with nature to live to old age, to be rich in money, to be healthy. But if you consider yourself as a man and part of a certain whole, on account of that whole it is a proper deed for you now to be sick, now to sail and run risks, now to be in want and, on occasion, to die before your hour.

"Discourses" II,5,25

(N34) - And when Zeus Itself is present within you and regards and gives hear to everything, are you not ashamed to be brooding and making these things, $\mathrm{O}$ insensible of your own nature, and object of divine disgust!

"Discourses" II,8,14

(N35) - Have we not by nature a sense of self respect? -We have it- Is the man who loses this not penalized, is he dispossessed of nothing, does he throw away nothing of what is his own?

"Discourses" II,10,22

(N36, 37, 38, 39) - Have we not by nature an attitude of faithfulness, by nature an attitude to cherish, by nature an attitude to be beneficial, by nature an attitude to tolerate one another?

"Discourses" II,10,23

(N40) - For we have come to this world without having by nature any concept of the right-angled triangle or of the half-tone diesis but we are taught about each of them through certain technical assumptions of knowledge.

"Discourses" II,11,2 
(N41) - The cause is that we have come into this world as if we had been already taught by nature in this topic and, taking impulse from these teachings, we have added our conceit on to them.

"Discourses" II,11,6

(N42) - We are anxious about our body, about our petty estate, about what Caesar will think, but about none of the things inside us. Are we anxious about not conceiving the false? -No, for that is in my power- Are we anxious about impelling against nature? -Not even about this-

"Discourses" II,13,11

(N43) - For when did he ever hear from anyone what is praise, what is censure and which is the nature of each? What kinds of praise have to be pursued and what kinds of censure have to be avoided?

"Discourses" II,16,7

(N44) - Dare to look up to Zeus and say: [...] Do you dispose me to hold office, to be a private citizen, to remain, to go into exile, to be poor in money, to be rich in money? About all these things I shall speak in your defence to the people; I shall show what the nature of each thing is.

"Discourses" II,16,42

(N45) - Neither money's wealth nor body's health nor reputation nor anything else are, in short, in our exclusive power, except the right use of impressions. This only is by nature unhampered, unhindered.

"Discourses" II,19,32

(N46) - Why, then, do you not accomplish the work? Tell me the cause. For this cause is either in me or in you or in the nature of the business.

"Discourses" II,19,33

(N47) - Instead of concealing it, this is what you ought to say to your Epicurean fellows and especially convince them, before you convince all other people, that we are born by nature sociable, that self-restraint is a good thing, so that all may be kept for you.

"Discourses" II,20,13

(N48) - What was, then, that awoke him (Epicurus) from his sleep and that constrained him to write what he wrote? What else but what is the strongest thing in men: nature, dragging him unwilling and groaning to its own plan?

"Discourses" II,20,15

(N49) - So potent and invincible a thing is human nature. For how can a vine be moved not like a vine but like an olive tree; or an olive tree, again, not like an olive tree but like a vine? It is unmanageable, it is inconceivable.

"Discourses" II,20,18

(N50) - Even getting from nature measures and standards for the discernment of truth, one does not work artfully to add up and refine what is lacking but, on the opposite, he tries to tear away and lose whatever power cognitive of the truth he has.

"Discourses" II,20,21 
(N51) - If I had had three or four fellow-servants of one mind with me, I would have made him hang himself bursting open with rage or transpose his mind. Now, on the contrary, those people sneer at us, because they use all that is given to them by nature while abolishing it in their discourses.

"Discourses" II,20,31

(N52) - This is a stupidity and a clumsiness of those who do not know the nature of each thing but fear that if one becomes aware of the difference, straightaway he leaves swept away and defeated.

"Discourses" II,23,33

(N54, 55) - Since we see that the dog is born for a certain thing, the horse for another one and the nightingale, perhaps, for yet another; in general it would not be absurd to declare that each creature is at that time wonderful, when it achieves the excellence of its nature, and since the nature of each is different, I think that each of them is wonderful of a different wonderfulness, or not?

"Discourses" III,1,3

(N56) - Does not, then, what makes a dog wonderful make a horse ugly and what makes a horse wonderful make a dog ugly, if their natures are different?

"Discourses" III, 1,4

(N57) - You sir, some special creature sprouts in every species: among oxen, among dogs, among bees, among horses. Do not tell this special creature "You, then, what are you?" Otherwise, taking a voice from somewhere it will say: "I am such as the purple in the robe. Do not urge me to be similar to the others and do not find fault with nature because it made me different from the others."

"Discourses" III,1,23

(N58) - Come on, what other appellations do you have? Are you male or female? -Male- Embellish, then, the male, not the female. The female has been born by nature smooth and effeminate, and if she is very hairy she is a prodigy and is shown at Rome among the prodigies.

"Discourses" III,1,27

(N59) - And if a male is not hairy by nature, he is a prodigy; but if he himself cuts off and plucks out his hairs, what shall we do with him?

"Discourses" III,1,28

(N60) - You sir, which kind of reason have you to bring charges to your nature? That it begot you male? What then? Ought it beget all females?

"Discourses" III,1,30

(N61) - Why, then, do you flatter the physician? [...] Why do you not give him back just what is his due? As I give it to the cobbler for the foot, to the carpenter for the house, so I give it also to the physician for the body, for what is not mine, for what is by nature corpse-like.

"Discourses" III,10,15 
(N62) - Our practice must not be done through exhibitions against nature and bizarre, since in that case we, who say to do philosophy, will differ in nothing from the mountebanks.

"Discourses" III,12,1

(N63) - As Socrates told us not to live an unexamined life, so one ought not to accept an unexamined impression, but we must say: [...] "Do you have from nature the token that must have the impression that will be accepted?"

"Discourses" III,12,15

(N64) - Some say that Zeus does this, when it is alone during the conflagration of the Universe. For taking impulse from something natural, namely from the fact that it is by nature sociable, unselfish, that with pleasure interacts with people, they do not think possible to enjoy oneself alone.

"Discourses" III,13,5

(N65) - Every great art or faculty is unsafe for the beginner. [...] other activities too are in accord with nature but do not suit a consumptive.

"Discourses" III,13,20

(N66) - You sir, analyse first what this business is and then also your nature, what you can bear. If you want to be a wrestler see your shoulders, your thighs, your loins.

"Discourses" III,15,9

(N67) - "Sickness, what will you make of it?" I'll show its nature, I'll stand out in it, I'll be stable, serene, I'll not flatter the physician, I'll not wish to die. "Discourses" III,20,14

(N68) - "How can, then, anything that pertains to the body be any longer unhindered? How can something that by nature is corpse-like, is earth, is clay, be great or renowned?

"Discourses" III,22,41

(N69) - Show me the tokens of the leadership, like those the queen bee has by nature. But if you are a drone that sues for the kingdom of the bees, don't you think your accomplices in the city business will knock you down like the bees do with the drones?

"Discourses" III,22,99

(N70) - All is full of friendly presences, first of gods and then of men, made kinsmen with one another by nature.

"Discourses" III,24,11

(N71) - The man, besides being by nature high-minded and able to despise everything that is aproairetic, has had also the quality of not being rooted nor clutched to the earth but to hasten from place to place, sometimes for some urgent needs, sometimes also for the vision itself.

"Discourses" III,24,12 
(N72) - When, then, neither the so-called kings nor the friends of the kings live as they want, who are anymore free men?- Seek and you will find. For nature has given you the resources for finding the truth.

"Discourses" IV,1,51

(N73) - Is not my hand mine?- It is a part of you, but by nature it is clay, it is the hampered, constrained servant of everything that is stronger than it.

"Discourses" IV,1,78

(N74) - For, when does a vine fare badly? When it fares contrary to its own nature.

"Discourses" IV,1,121

(N75) - A man too, then. And which is his nature? To bite, to kick, to throw into prison and behead? No, but to do well, to cooperate, to wish good things.

"Discourses" IV,1,122

(N76) - Why do we say a paradox if we say that everything's evil is what is contrary to its own nature? Is this a paradox?

"Discourses" IV,1,125

(N77) - But as we say that the nature of the man is tame, unselfish, faithful, this is not a paradox.

"Discourses" IV,1,126

(N78) - Is it not, then, in like manner that a person has ill fortune not when he cannot choke lions or embrace statues (for he has come into the world having from nature certain faculties not to this end) but when he has lost his good intelligence, his faithfulness?

"Discourses" IV,5,14

(N79) - This is the nature of every being: to pursue his good, to flee from his evil; to believe an enemy, a treacherous fellow, he who deprives us of the first and encompasses us with the opposite, even though he is a brother or a son or a father.

"Discourses" IV,5,30

(N80, 81) - Let's at least ripen in accord with nature. Why do you strip us naked, why do you force us? We cannot yet bear with the air. Allow the root to grow and acquire the first knee, then the second, then the third; and so the fruit will project itself out by force of nature, even if I don' $t$ want this.

"Discourses" IV,8,40

(N82) - A bull does not ignore its own nature and preparation when a wild beast appears, nor does it await the one who will encourage it; nor does a dog ignore it when it sees some wild creature.

"Discourses" IV,8,42

(N83) - Some people dispute whether sociability is included in the nature of human beings; yet these same people, so I deem, would not dispute that a sense of cleanliness is quite included and that, if for nothing else, for this quality a man is separated from the other animals.

"Discourses" IV,11,1 
(N84) - And we think cleanliness to be something specific to the man, taking this characteristic in the first place from the gods. Since they are by nature pure and undefiled, and as much as men have approached them in terms of reason, the more they cling to what is pure and clean.

"Discourses" IV,11,3

(N85) - It was unattainable that snivel would not run from our nose, man being the mixture that we know. For this reason nature made hands and made nostrils exactly like tubes to discharge the fluids. If, then, one gulps them down, I say that he is not doing a man's work.

"Discourses" IV,11,9

(N86) - If nature had committed to your care a horse, would you overlook and neglect it? Now, think that your body has, like a horse, been put in your care: wash it, wipe it off, do it so that no one may turn away or turn aside.

"Discourses" IV,11,17

(N87) - For this you have special in yourself, while the body is by nature only clay. Why do you toil for it to no purpose? Time will make you recognize, if nothing else, that it is nothing.

"Discourses" IV,11,27

(N88) - Nature did not made filthy even those animals that live in common with human beings. Does perhaps a horse roll itself into the mire? Or does a purebred dog? No, but the hog, the rotten geese, the worms, the spiders, the creatures disbanded as far as possible from correlation with men.

"Discourses" IV,11,31

(N89) - Where is it possible to find these things easily nowadays? Or let someone show me a man so minded that he can say: "I only care about what is mine, what is not hampered, what is free by nature. This, which is the substance of the good, I have."

"Discourses" IV,13,24

(N90) - Furthermore the things in our exclusive power are by nature free, unhampered, unimpeded, while the things not in our exclusive power are weak, servant, hampered, are another's.

"Manual" E1,2

(N91) - It is possible to decipher the plan of nature from the consideration of the points in which we do not differ from one another. For example, when another' s boy breaks the drinking-cup, you have straightaway ready at hand the words: "These are things that happen!"

"Manual" E26

(N92) - As a target is not set in order to fail it, so neither the nature of evil exists in the world.

"Manual" E27 
(N93) - You sir, examine first what is the business and then decipher also your nature, if you can bear it. Do you decide to be a pentathlete or a wrestler? See your arms, your thighs, decipher your loins.

"Manual" E29,5

(N95) - And you deem the human being a creature made for himself or for society? -For society- By what? -By nature- What this and how it governs the whole and whether it exists or not, these are issues it is no longer necessary to meddle in.

"Fragment" F1

(N96) - But above all else, the work of nature is to tie and reconcile our impulse to the impression of befitting and beneficial.

"Fragment" F6

(N97) - Such was, is and will be the nature of the world, and it's impossible for the events to happen otherwise than they do now.

"Fragment" F8

$(\mathrm{N} 98,99,100)-[\ldots]$ and then they bring forward those ill-tempered philosophers who think pleasure not to be in accord with nature but to supervene to things in accord with nature, as justice, temperance, freedom. Why, then, does the soul rejoice and find peace through the body's goods, that are smaller, as Epicurus says, while it does not delight in its own goods, that are the greatest? Yet nature has given me self respect and many times I blush, when I conceive something shameful to say. This motion does not allow me to set physical pleasure as good and end of life.

"Fragment" F14

(N101, 102, 103) - Amazing is nature and, as Xenophon says, fond of her creatures. [...] When nature, that gave us the body, takes it off why, then, don' t you tolerate it? -I love it- someone says. But, as I was saying now, is it not nature that has given you also this very love? And it says: "Give it up by now and have no more troubles."

"Fragment" F23

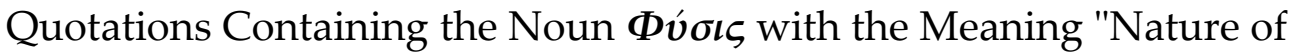 Things"}

(NOT1) - That is why we especially need education to diairesize, so as to learn to adapt our preconception of reasonable and unreasonable to particular substances, in harmony with the nature of things.

"Discourses" I,2,6

(NOT2) - Slave! I don't seek that, but how you impel and repel, how you desire and avert, how you design, you propose and prepare: if in harmony with the nature of things or out of harmony with it.

"Discourses" I,4,14 
(NOT3) - Where is, then, our profit? If any among you, diverting himself from external objects has turned towards his own proairesis, working at it and doing all he can so as to make it to come out in harmony with the nature of things: elevated, free, unhampered, unhindered, faithful, self respecting.

"Discourses" I,4,18

(NOT4) - Take my books and you will recognize how consequent and in harmony with the nature of things is what makes me a self-controlled man. "Discourses" I,4,29

(NOT6) - Naturally, said the officer- But really persuade me about this [...] and I'll persuade you that any event that is in accord with the nature of things happens rightly.

"Discourses" I, 11,5

(NOT7) - Since for this reason one should then say that also tumors are born for the good of the body, just because they are born; and in short that to aberrate is in accord with the nature of things, because almost all of us or at least most of us do aberrate.

"Discourses" I,11,7

(NOT9) - Then, since we dispute about what happens in accord with the nature of things and happens rightly or not rightly, what criterion do you want that we assume?

"Discourses" I,11,10

(NOT10, 11) - And yet to ignore the criterion of colours, of odors, and of flavors is not, perhaps, a great penalty; but do you think small the penalty for the fellow who ignores the criterion of good and evil, of what is in accord with the nature of things and of what is not in accord with the nature of things?

\section{"Discourses" I,11,11}

(NOT12) - You, then, said Epictetus, now that you are aware of this, you will be eager for nothing else and will devote your intelligence to nothing else but, once you have deciphered the criterion of what is in accord with the nature of things, to exploit it so as to distinguish each particular case.

"Discourses" I,11,15

(NOT13, 14) - Do you think affection to be in accord with the nature of things and beautiful? -And how not so?- But what? While affection is in accord with the nature of things and beautiful, what is rational is it not beautiful?

"Discourses" I,11,17

(NOT15, 16) - Not at all- Therefore does what is rational contradict affection? -I don't think so- Otherwise, when one of the contradictory terms is in accord with the nature of things, is it necessary that the other be not in accord with the nature of things? Or not?

"Discourses" I,11,18 
(NOT17) - What is, then, left behind or what device can we find in order to use with people? Such a use that, while they will do what appears right to them we will, nonetheless, be in accord with the nature of things.

"Discourses" I,12,19

(NOT18) - "In every circumstance I'll keep my ruling principle in accord with the nature of things." -Whose ruling principle?- "The one in whom I am." "Discourses" I,15,4

(NOT19) - This I seek, how I may be in accord with the nature of things even if my brother is not reconciled with me.

"Discourses" I,15,6

(NOT20) - He climbs up the Capitol and offers a sacrifice. Now, who ever sacrificed for having desired as a virtuous man, for having impelled in accord with the nature of things? For where we set our good, there we also thank the gods.

"Discourses" I,19,25

(NOT21) - You sir, what is it that you want to happen to you? I am content if I desire and avert in accord with the nature of things; if I use impulse and repulsion as I have been born to do; and if I similarly employ purpose, design and assent.

"Discourses" I,21,2

(NOT22) - What does it mean, then, to educate ourselves? It means learning to adapt our natural preconceptions to the particular substances and cases in a way appropriate to the nature of things and, well then, to discriminate that, among things, some are in our exclusive power while others are not in our exclusive power.

"Discourses" I,22,9

(NOT23) - That is why Demetrius said to Nero: "You threaten me with death, but the nature of things threatens you."

"Discourses" I,25,22

(NOT24) - As someone was reading the hypothetical arguments, Epictetus said: This also is a law of the hypothetical arguments, that we accept what follows from the hypothesis. And before all else, it is the law of life that we perform what follows from the nature of things.

"Discourses" I,26,1

(NOT25) - For if we decide, on every subject matter and in every circumstance, to keep ourselves in accord with the nature of things, it's plain that in everything we must make a point of neither escaping what is consequent with it nor accepting what contradicts it.

"Discourses" I,26,2

(NOT26) - For if you dispose to keep your proairesis in accord with the nature of things, all safety is yours, every facility is yours, you have no trouble.

"Discourses" II,2,2 
(NOT27) - Must you use these external objects carelessly? Not at all. For this again is an evil for our proairesis and, through this way, is not in accord with the nature of things.

"Discourses" II,5,6

(NOT28) - For this reason Chrysippus says well: "As long as the consequences of something are doubtful to me, I always cleave to the judgements more thoroughbred for obtaining what is in accord with the nature of things, for Matter Immortal itself made me able to select them."

"Discourses" II,6,9

(NOT29) - But if you say to someone: "Your desires are inflamed, your aversions are those of a slave-minded fellow, your designs are inconsistent, your impulses are out of harmony with the nature of things, your conceptions are rash and false;" straightaway he goes out and says: "He outraged me!"

"Discourses" II,14,22

(NOT30) - For we must take care of the eyes, but not as the most powerful thing; but also of the eyes for the sake of what is more powerful. Because this latter will not stay in accord with the nature of things unless it works rationally with the eyes and chooses certain objects instead of others.

"Discourses" II,23,35

(NOT31) - You sir, your program was to fashion yourself able to use the impressions that befall you in a way which is in accord with the nature of things: unfailing in desire, unstumbling in aversion, never misfortuned, never having ill fortune, free, unhampered, unconstrained; reconciled to the government of Zeus, obedient to this government, being well pleased of this government; not blaming anybody, not imputing anybody.

"Discourses" II,23,42

(NOT33) - I have to tell you only this: that the person [...] who will neither desire, nor avert, nor impel, nor design, nor assent, nor dissent, nor suspend his judgment in accord with the nature of things; on the whole this person will go around deaf and blind, thinking to be somebody when, instead, he is nobody.

"Discourses" II,24,19

(NOT34) - Any rational mind is by the nature of things filled with suspicion and resentment against the contradiction, yet till the mind does not understand to be in contradiction, nothing prevents it to make contradictory things.

"Discourses" II,26,3

(NOT35) - You are a human being: that is a mortal creature able to use the impressions rationally. What is rationally? Acknowledging the nature of things and perfectly.

"Discourses" III,1,25

(NOT36) - The subject matter of the virtuous man is his own ruling principle, the body is the subject matter of the physician and of the masseur, 
the land is the subject matter of the farmer. The work of the virtuous man is the use of the impressions in accord with the nature of things.

"Discourses" III,3,1

(NOT37) - What then? Upon entering the theatre, ought one say: "Come on, let Sophron be crowned?" No, but that: "Come on, let me keep, on this subject matter, my proairesis in accord with the nature of things."

"Discourses" III, 4,9

(NOT38) - Go away; take care of things at home. For if your ruling principle cannot stay here in accord with the nature of things, a bit of land will do the job: you will grow your small coins, you will assist your old father, you will revolve around the market-place, you will hold office.

"Discourses" III,5,3

(NOT39) - Now one has labored to resolve syllogisms, and there are profits. Then, instead, one labored with the aim of keeping our ruling principle in accord with the nature of things, and there were profits.

"Discourses" III,6,3

(NOT40) - Do not exchange, then, one thing for the other and do not seek, when you do all you can in one topic, to profit in another one. See whether any of us does not make profits when he decides to stay and enjoy himself in accord with the nature of things. You will find none.

"Discourses" III,6,4

(NOT41) - To these $<$ duties $>$ subordinate the physical pleasure as a minister, as a manservant, that it may stimulate our spirited vigour, that it may chair our works in accord with the nature of things.

"Discourses" III,7,28

(NOT42) - But to what end have the philosophers, then, general principles?To this end: to have our ruling principle in accord with the nature of things and enjoy ourselves, whatever will come about.

"Discourses" III,9,11

(NOT43) - What, then, do I need?- What is not present in you: to be stable, to have the intellect in accord with the nature of things, to be undisconcerted.

"Discourses" III,9,17

(NOT44) - When I have these <faculties> in accord with the nature of things, why should I not work artfully also my reason?

"Discourses" III,9,19

(NOT45) - But am I not a scholar?- And to what purpose do you pursue your scholarship? Slave! Is it not to be serene? Is it not to be stable? Is it not to be and enjoy yourself in accord with the nature of things?

"Discourses" III,10,10

(NOT46) - What prevents you, when you have a fever, from having your ruling principle in accord with the nature of things?

"Discourses" III,10,11 
(NOT47, 48) - "How do I use the impressions that befall me? In accord with the nature of things or not in accord with the nature of things? How do I answer them? As one ought or as one ought not?"

"Discourses" III,16,15

(NOT49) - And then you tell me that in desire and aversion you conduct yourself in accord with the nature of things? Go, and persuade someone else. "Discourses" III,23,12

(NOT50) - What another fellow does not in accord with the nature of things, let it not become an evil for you.

"Discourses" III,24,1

(NOT51) - If You send me where it is not possible to enjoy oneself as a man in accord with the nature of things, I quit this life not to disobey You but because You are giving me a signal for retreat.

"Discourses" III,24,101

(NOT52) - If, on the contrary, You give me a way of enjoying myself in accord with the nature of things, I'll not seek other place than that in which I am.

"Discourses" III,24,102

(NOT53) - What then, is the cause of this? That we never read for this purpose, never wrote for this purpose, that in our daily work we may use the impressions that befall us in accord with the nature of things, but we end by learning what is said and by being able to explain it to someone else, by resolving a syllogism, by scouring a hypothetical argument.

\section{"Discourses" IV,4,14}

(NOT54) - "But they cry down to me." Your hearing, then, is hindered. What, then, is this to you? Is the faculty that uses the impressions perhaps also hindered? And who prevents you from using desire and aversion, impulse and repulsion in accord with the nature of things?

"Discourses" IV,4,28

$($ NOT55, 56) - If he does only what is exclusively his own to do, not even Socrates is sufficient to convince those people to keep their proairesis in accord with the nature of things; for this, their proairesis, is what is another's. But Socrates is up to this task: that while those people do what is exclusively theirs as they think it fitting for them, he nevertheless will stay and enjoy himself in accord with the nature of things.

\section{"Discourses" IV,5,5}

(NOT57) - For this is always the program of the virtuous man. To obtain a praetorship? No; but if this is given to him, to keep his ruling principle, upon this subject matter, in the due order. To marry? No; but if marriage is given to him, to keep himself, upon this subject matter, in accord with the nature of things.

"Discourses" IV,5,6 
(NOT58) - The others will see whether it is advantageous for them to behave and enjoy themselves in a manner not in accord with the nature of things; as for me no one is nearer to me than myself.

"Discourses" IV,6,11

(NOT59) - The substance of the good and of the evil is it not a proairetic thing? -Yes- You have, then, the power to use everything that comes about in accord with the nature of things.

"Discourses" IV,10,8

(NOT60) - But if you want anything that is another's, you have lost what is yours. This is the nature of the things: nothing happens free of charge. What is amazing in that?

"Discourses" IV,10,19

(NOT61) - Oil will be spilled, my vessels will be lost but I'll maintain my self control. During my absence there will be a fire and my books will be lost, but I'll use my impressions in accord with the nature of things.

"Discourses" IV,10,26

(NOT62) - For in the first place a habit [...] of not paying attention emerges; and then a habit of delaying attention, and so you are accustomed to always defer from one time to another your serenity, a decorous behaviour, to be and enjoy yourself in accord with the nature of things.

"Discourses" IV,12,2

(NOT63) - Remember, then, that if you think free what by the nature of things is servant and your peculiar what is another's, you will be hindered, you will mourn, you will be disconcerted, you will blame both gods and men. "Manual" E1,3

(NOT64) - He who fails in desire is misfortuned, while he who stumbles on what he averts has ill fortune. If, then, among what is in your exclusive power, you avert only what is not in accord with the nature of things, you will stumble on nothing of what you avert.

"Manual" E2,1

(NOT65) - Remove, then, your aversion from all that is not in our exclusive power and transpose it on what, among the things that are in our exclusive power, is not in accord with the nature of things. For the time being, totally abolish your desire.

"Manual" E2,2

(NOT66, 67) - If you go away for a warm bath, put in front of you the events at the baths: those who sprinkle, those who jostle, those who revile, those who steal. And thus you will undertake the work more safely, if at once you will say: "I dispose to take a warm bath but also to keep my proairesis in accord with the nature of things." And behave in the same way for each work. For thus, if any hindrance to take a warm bath happens, you will have ready at hand that: "Yet I did not dispose only this, but also to keep my proairesis in accord with the nature of things; and I'll not so keep it, if I am vexed at the events."

"Manual" E4 
(NOT68) - What is, then, yours? The use of impressions. Therefore at that time be elated when you behave in accord with the nature of things in the use of impressions; for then you will be elated at some goodness of yourself. "Manual" E6

(NOT69) - And if some people think that you are somebody, distrust yourself. For know that it is not easy to guard your proairesis working in accord with the nature of things and the external objects, but if you take care of the first one it's inevitable for you to neglect the others.

"Manual" E13

(NOT71) - He has removed from himself every desire and has transposed aversion only upon what, among what is in our exclusive power, is not in accord with the nature of things.

"Manual" E48,3

(NOT72) - When one takes a solemn air because he is able to comprehend and explain the books of Chrysippus, say to yourself: "If Chrysippus had not written obscurely, this fellow would have nothing about which to take a solemn air." What do I decide? To decipher the nature of things and to stay in her company.

"Manual" E49

(NOT73, 74, 75, 76) - Generally do you call misfortune of a man what is not a failure of man's nature? And do you think a failure of man's nature what is not against the plan of his nature? What then? You have learned the plan of man's nature. Does what has occurred prevent you to be just, magnanimous, temperate, judicious, not precipitate, not deceitful, self respecting, free and the other things thanks to the presence of which man's nature has what is peculiar to it? Well then, in the face of anything that promotes you to a grief, remember to use this judgements: "Not that this is a misfortune but that to bear generously with it is a good fortune."

"Fragment" F28b

\section{Quotations Containing the Noun $\Phi v$ бı $\varsigma$ with the Meaning "Nature" and then with the Meaning "Nature of Things"}

(N3) (NOT5) - That is why it is shameful for a man to begin and to end where the creatures lacking reason also do. He should rather begin where they do, but end where nature also ended in dealing with us. And she ended on the knowledge of general principles, understanding of the use of impressions and oneself's enjoyment in harmony with the nature of things.

"Discourses" I,6,20-22

(NOT8) (N5) - You show me, then, how it is in accord with the nature of things. - I cannot, said the officer. You, rather, show me how it is not in accord with nature and does not happen rightly.

"Discourses" I,11,8 
(N53) (NOT32) - Do we know, then, what a man is, what his nature is, what the concept of man is? Do we have on this subject pierced ears? Do you have the concept of what the nature of things is and can you, and how much, follow me when I speak?

"Discourses" II,24,12

(N94) (NOT70) - The proper deeds are generally calibrated upon our social relationships. He is a father: what is dictated is to take care of him, to give him way in everything, to tolerate him if he reviles, if he smites. "But he is a bad father." Were you made by nature kinsman to a good father? No, but simply to a father. "My brother does me wrong." Keep, therefore, your position with regard to him and do not consider what he does but what you do in order to have your proairesis in accord with the nature of things. For another person will not damage you, if you do not dispose so.

"Manual" E30

Grand Total

179 times
(N) "nature"
103 times
(NOT) "nature of things"
76 times

\section{Conclusion}

Let us now follow a step by step process in order to better understand what is the "nature of things" according to Epictetus.

a) Nature $(\mathrm{N})$ and Truth. According to the Stoics, in "nature" there are no contradictions whatsoever but only contrasts, clashes, real conflicts. ${ }^{21}$ So pain does not contradict pleasure but is something opposed to it. Death does not contradict life but is its opposite; and, in general, opposite qualities cannot coexist at the same time in the same entity. Nor is there in "nature" anything that can be called false, because its mere existence makes it an entity whose truth is thereby automatically and inherently qualified..$^{22}$ "Nature" is then a synonym of true things and therefore considered as the most comprehensive and primitive of the deities, it is also called by the Stoics "Truth" and the source of all truth. ${ }^{23}$ If nature makes only true things, all sorts of opposite things must be considered equivalent and at the same level.

b) Proairesis $(\mathrm{P})$. If man is one of the many creatures that "nature" has been able to generate, the same "nature" gave him something that no other creature has been endowed with: the proairesis, ${ }^{24}$ that is the faculty allowing him to

21. Stobaeus, "Stoicorum Veterum Fragmenta" (Book II, Fragment 913).

22. Cicero, "Stoicorum Veterum Fragmenta" (Book II, Fragment 921).

23. Marci Aurelii Antonini, "Ad se ipsum" (To himself) (Book IX, ch. 1, 1-5).

24. Epictetus, "Discourses" (Book I, ch. 17, 21). 
understand the use that he makes of his impressions, the ability to distinguish between good and evil, happiness and unhappiness, etc. Irrespective of the ways in which the proairesis of a man works, obviously these activities ${ }^{25}$ will always be, by definition, "natural" and will never be "contrary to nature." In fact, if these were possible, it would mean that nature has created something that is no longer nature, namely that such man is no longer part of the "nature" that generated him: which is absurd. ${ }^{26}$

c) Nature of things (NOT). It is owing to the proairesis that "nature" has endowed us with, that the man is able to recognize the following empirical, observable, evident fact: of all the existing things, some are in our exclusive power while some others are not. ${ }^{27}$ As Epictetus tells us in the first lines of his "Manual," the "nature of things" is exactly their fundamental bipartition in two sets: the first set is represented by all the entities that depend exclusively on us: like our judgments, impulses, desires, aversions, assents, etc. The second is the set of all the entities that do not depend exclusively on us: like our body, property, reputation, titles, etc. The first is the set of "proairetic" things, the second is the set of "aproairetic" things. ${ }^{28}$

d) Nature and the Nature of things. This fundamental bipartition of things, this "diairesis" which divides them into two distinct and clearly distinguishable sets is entirely natural, is written in the things themselves, is completely independent of how human proairesis works, and our proairesis has the ability to recognize it but no possibility at all to suppress or change it. ${ }^{29}$ This is the empirically evident structure of "nature," that appears to the human proairesis and that can be properly called "nature of things." 30 The truth of "nature" $(\mathrm{N})$ appears then, to the human proairesis $(\mathrm{P})$, disguised as the "nature of things" (NOT), and its existence can be called Truth itself. ${ }^{31}$ It is in relation to this truth, i.e. to the "nature of things," that we can behave in harmony or in contrast; whereas whichever cultural model we follow, this will always be in harmony with "nature." It is in relationship, not to "nature" but to the "nature of things" that we choose every time a specific attitude; and it is a direct and immediate consequence of our choice if we live a happy life when we are in harmony with the nature of things, and an unhappy one when we are in contrast with it. ${ }^{32}$

\footnotetext{
25. Ibid., "Discourses" (Book I, ch. 29, 1).

26. Ibid., 12-13.

27. Ibid., "Manual" (I, 2-3).

28. Ibid., "Discourses" (Book I, ch. 30, 3).

29. Ibid., "Discourses" (Book II, ch. 2, 2).

30. Ibid., "Discourses" (Book II, ch. 5, 6).

31. Ibid., "Discourses" (Book IV, ch. 1, 51).

32. Ibid., "Discourses" (Book I, ch. 18, 9).
} 
e) Diairesis and counterdiairesis. Since "nature" is an all-encompassing entity, diairesis and counterdiairesis, ${ }^{33}$ virtue and vice, justice and injustice, falsehood and sincerity, and in short any other pair of possible opposites, are all fully natural choices. ${ }^{34}$ And since the "nature of things" is inviolable, man can commit the worst crimes and feed the most perverse viciousness in the complete indifference both of "nature" and of the "nature of things." According to Epictetus, for example, an unjust act is simply a form of the many that can take the denial of the existence of the "nature of things." And we deny the existence of the "nature of things" when we judge that something is proairetic when it is aproairetic, or that something is aproairetic when in fact it is proairetic. ${ }^{35}$

f) Contradiction and unhappiness. At last, it is never "nature" that suffers the counterstroke of our denial of the "nature of things," but only our individual proairesis. This counterstroke has a name: contradiction. ${ }^{36}$ And contradiction entails aberration, passion, slavery, misery, unhappiness. The contradictions are an human peculiarity, and Epictetus tells us very clearly that any fellow who wants something in violation of the "nature of things" ignores that he summons in this way his own unhappiness, because every aberration of the human being includes a contradiction. Yet until we do not understand this, we will nod to falsehood as to something true. ${ }^{37}$

\section{Bibliography}

Antonini, Marci Aurelii. "Ad se ipsum" (To himself). Book II, ch. 3. "Ad se ipsum" (To himself). Book IX, ch. 1.

Cicero. "Stoicorum Veterum Fragmenta." Book II, Fragment.

Cassanmagnago, Cesare. Epitteto: Diatribe, Manuale, Frammenti. Rusconi Editors, 1982.

Dalfen, Joachim. Marci Aurelii Antonini "Ad se ipsum Libri XII" (The Emperor Marcus Aurelius Antoninus "To himself, books 12"). Leipzig: Teubner, 1979.

Diogenes, Laertius. Stoicorum Veterum Fragmenta. Book III, Fragment.

Dobbin, Robert. Epictetus. Discourses Book I. Oxford: Oxford University Press, 2008.

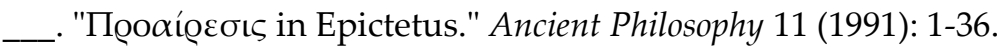

Epictetus. "Discourses." Book I, ch. 17.

_. "Discourses." Book I, ch. 18.

_. "Discourses." Book I, ch. 27.

33. Scalenghe, "Epictetus: Diairesis and Contradiairesis."

34. Epictetus, "Discourses" (Book II, ch. 6, 24).

35. Ibid., "Discourses" (Book II, ch. 16, 28).

36. Ibid., "Discourses" (Book II, ch. 26, 1).

37. Ibid., 3. 
. "Discourses." Book I, ch. 29.

. "Discourses." Book I, ch. 30.

. "Discourses." Book II, ch. 2.

. "Discourses." Book II, ch. 5.

. "Discourses." Book II, ch. 6.

. "Discourses." Book II, ch. 16.

. "Discourses." Book II, ch. 26.

. "Discourses." Book IV, ch. 1.

"Manual." I.

Hadot, Pierre. Manuale di Epitteto. Einaudi Editors, 2006.

Oldfather, William Abbott. Epictetus. The Discourses as reported by Arrian, the Manual and the Fragments. London: Heinemann, 1961.

Scalenghe, Franco. "About the Arithmetic and the Geometry of Human Proairesis and the Natural Asymmetry by Which Unhappiness Wins the Game Against Happiness 3 to 1." International Journal of Philosophy 3, no. 6 (2015): 72-82.

_. "Proairesis, Proairetic and Aproairetic: Synopsis of All the Passages Containing these Terms in the "Discourses" and the "Manual" of Epictetus." International Journal of Philosophy 3, no. 3 (2015): 24-33.

. The nature of things. A dialogue. Available online at www.epitteto.com, 2014.

_. "Epictetus: Diairesis and Contradiairesis." Prometeus Ano 7, no. 15, Janeiro-Junho (2014).

Stobaeus. "Stoicorum Veterum Fragmenta." Book II, Fragment.

von Arnim, Hans. "Stoicorum Veterum Fragmenta" (Stoic Ancient Fragments). Leipzig: Teubner, 1905. 